\title{
GENDER-BASED SUSTAINABLE DISASTER RESPONSE EDUCATION TO ANTICIPATE THE PROBLEM OF WOMEN'S VULNERABILITY
}

\author{
*Yudi Hartono \\ Faculty of Teacher Training and Education, Universitas PGRI Madiun, Indonesia \\ Email: yudihartono@unipma.ac.id
}

*Corresponding Author, Received: March 17, 2021. Revised: March 27, 2021. Accepted: May 26, 2021

\begin{abstract}
This study revealed the condition of women during a disaster in Indonesia, roles, rights and their fulfilment, and anticipates the problem of women's vulnerability in disasters. The method used was a literature study. Sources of data were from books, journals, research reports, mass media and other relevant literature sources. Data validation was done using source triangulation. The data was analyzed using interactive analysis. The results show that the condition of women during a disaster in Indonesia was faced with various vulnerabilities which resulted in a large percentage of the number of victims. However, in of such vulnerabilities, women could act as a driving force for their families and their environment to take disaster risk reduction actions. Women struggled to maintain the survival of their families and society, although, on the other hand, their rights tended to be neglected due to gender-biased socio-cultural constructions. The rights of women could not be properly guaranteed and it became even more difficult during a disaster. Women's vulnerability can be anticipated with gender-based sustainable disaster responses education that involves men and women with attention to women's rights during a disaster through formal and non-formal education.
\end{abstract}

Keywords: Gender-Based Education, Disaster Response, Woman Vulnerability

This work is licensed under the Creative Commons Attribution-ShareAlike 4.0

International License

\section{INTRODUCTION}

Indonesia is one of the countries prone to disasters, both geological disasters such as earthquakes, volcanic eruptions, landslides, tsunamis, and hydrometeorological disasters such as floods, droughts, tides and high waves. Geographically, Indonesia is located at the junction of 4 (four) tectonic plates, namely: the Eurasian Plate, the Indian Plate, the Australian Plate and the Pacific Oceanic Plate. Indonesia is also situated at the confluence of three mountain groups: the Alpine Mountains, the Circum-Pacific and the CircumAustralia. Indonesia has more than 500 volcanoes and 128 of them are still active. Indonesia is also among the countries most potentially affected by climate change. There is a strong link between climate change and disasters. Climate change will cause disasters such as floods and drought, as well as invisible changes that have the potential to have a greater impact, so a longer adaptation strategy is needed [1].

A disaster is an event or a series of events that threatens and disrupts people's lives and livelihoods caused by natural and/or non-natural factors or human factors, resulting in casualties, environmental damage, property loss and psychological impacts [2]. A disaster is an event that occurs because the trigger, threat (hazard) and vulnerability components work together systematically to cause risks to the community [1]. Disasters often occur unexpectedly and the resulting consequences can be extraordinary. Apart from the loss of life and property, it can also change the elements of community life, sudden poverty, trauma, damage to the built environment and disease [3].

Disasters can be divided into three types, namely natural, non-natural and social disasters. Natural disasters are disasters caused by an event or series of events generated by nature, including earthquakes, tsunamis, volcanic eruptions, floods, droughts, hurricanes and landslides. Non-natural disasters are disasters caused by non-natural event or series of events, which include technological failure, modernization failure, epidemics and disease outbreaks [2]. The Lapindo mudflow disaster in Sidoarjo, East Java, can be categorized as a non-natural disaster. As for social disasters, they are disasters caused by an event or a series of events due to human behaviour such as social conflicts and terror [2]. Several social conflicts that resulted in casualties are conflicts in Poso, Ambon, North Maluku, Pontianak, Sampit and various other places.

The same disaster can have different implications for men and women. One of the causes 
is the difference in vulnerability to disasters. Disaster risk is distributed differently among communities. Vulnerability is influenced by a variety of complex factors. One of them is the difference in access and control over the resources needed, both for survival and during the postdisaster recovery period. Women and girls are groups of people with a high risk of disaster [4].

Differences in vulnerability might also be caused by social and cultural contexts that affect women's capacity to anticipate, prepare for, survive and recover after a disaster. Another factor is the lack of attention to women's special needs such as sanitary napkins, underwear, sanitation and clean water to keep reproductive organs clean, proper and safe bathing, washing and toilet facilities, as well as multivitamins for pregnant and lactating women. In addition, there is also a lack of women's involvement in disaster management, so that the aspirations of women's needs cannot be accommodated.

Their vulnerabilities make the casualties are dominated by women, as well as children and the elderly. Mothers and children are the most vulnerable population to risky environmental conditions such as areas devastated by floods, drought, earthquakes and so on. The risk of a poor environment leads to increased maternal and child mortality.

The protective nature possessed by women is also a factor causing the high number of female victims in every disaster. During the disasters in Aceh and North Sumatra in 2004 and the Yogyakarta earthquake in 2006, many women died while hugging their children or protecting their children. They were generally staying at home with their children and were unable to run to a safer place.

The Aceh and North Sumatra tsunamis in 2004 claimed the lives of many women, in which the number was higher than the number of men [5]. The estimated numbers of survivors were mostly based on the ratio, according to World Vision records, an estimated $60 \%$ of victims were women with the ratio of survivors was 3:1 between male and female. Meanwhile, according to Oxfam, it reached up to $80 \%$ [6].

The London School of Economics and Political Science research on 141 countries that experienced disasters in the 1981-2002 period found data that women were the biggest victims of various natural disasters that had ever occurred. In a massive disaster, most victims are women. Research by Margaret Arnold of the World Bank revealed that $90 \%$ of the 140,000 deaths during the 1991 Bangladesh cyclone were women. In the 2004 Indian tsunami, the ratio of female deaths was 3 times the number of male. Meanwhile, in the 2004 Indonesia tsunami, the number of women who died was 4 times the number of men [7].

The vulnerability of women during disasterprone conditions in Indonesia which results in a large percentage of casualties is interesting to study regarding the overview of the condition of women, their roles and rights as well as their fulfilment in disasters, and anticipates the problem of women's vulnerability in disasters..

\section{RESEARCH METHODS}

The type of this research is a literature study. Sources of data were from books, journals, research reports, mass media and other relevant sources. Data validation was carried out by source triangulation, namely comparing data from one source with another. Data analysis used interactive analysis from Huberman and Miles [8]. The flow of analysis was data collection, data reduction, data presentation and verification or conclusion. Data from literature study results were reduced according to the focus of the study then unnecessary data was reduced. The results of data reduction were identified and classified to provide an overview of women during disasters, rights and their fulfilment, and were served as the basis for concluding about anticipation the problem of women's vulnerability in disasters.

\section{RESULT AND DISCUSSION}

\subsection{Women's conditions in disaster}

The condition of women during a disaster can be examined from the vulnerability they experience and the impacts it causes. Women are a vulnerable group or risk group, namely a group of people who are vulnerable to various threats and dangers because of their inherent conditions. They have special needs which, if not accommodated, can threaten their life. Therefore, it is important to ensure that vulnerable groups or risk groups are considered in disaster management, not only because their needs must be met, but also because of the possible valuable contribution of women.

In a disaster situation, women face almost the same problems. The ability to save oneself in a panic situation during a disaster is limited due to the conditions it carries. During the 2004 Aceh and North Sumatra tsunamis, women were generally staying indoors, while men were catching fish in the ocean while the boats were still floating and safe. Women have never learned to swim and wore long skirts making them difficult to escape [5]. During the tsunami in Pangandaran that occurred on July 17,2006 , many women could not swim and climb coconut trees, so they depended on men to save themselves. Some of the surviving women were dressed off because of the strong waves. They scavenged for the rest of the makeshift cloth and 
tore it up to be divided among them. During the Yogyakarta earthquake disaster in 2006, many women were unable to escape to a safer place.

After the disaster, the conditions of women are tougher than the other victims. During the evacuation, victims are usually placed in temporary shelters such as schools, government offices or emergency tents in open fields. The situations and conditions in such places are generally far from the standard of being able to live a life in accordance with the special conditions and needs of women who require a lot of privacy. Including the postdisaster vulnerability are the increased life pressure and workload on women.

In the early stages of the emergency response, some mothers with children only received one portion of food for one adult and there was an increase in early marriages after the tsunami [5]. Distribution systems and types of assistance often make it difficult to access and fulfil women's needs, as done by air by helicopter. Likewise, infrastructure development, both in reconstruction and development programs, often does not pay attention to the specific conditions and needs of women. In designing a house, for example, their special needs are not accommodated because most people took into account the speed of the process. They become a group that is at high risk of various threats of diseases and various psychological disorders.

Haryono, Koesbardiati and Kinasih's research from the Department of Anthropology, Faculty of Social and Political Sciences, Airlangga University on flood disasters in Lamongan and Bojonegoro shows that women's vulnerability can increase due to the nature of the disaster. Reproductive and sexual health, which is a vulnerability for women, receives less attention. Itching disease in the intimate organs tends to be less communicable to the medical team because of the embarrassment and taboo associated with the concept of genitalia (aurat). They only revealed an itchy disease in the body but did not mention reproductive health problems. Thus, information on reproductive problems is very lacking [9].

During the eruption of Mount Merapi in 2010, many women in Kinahrejo, Cangkringan, Sleman Regency, Yogyakarta, became widows because their husbands died. When the eruption occurred, the husband and son were looking for grass in the forest and did not return. Women live a double burden: raising children and taking care of the household, plus the burden of earning a living [10].

According to international research, women and men have different priority needs and approaches in disaster emergency recovery. Livelihoods, access to housing, water and sanitation facilities and psychosocial counselling are usually the highest priorities for women, while men's priority is large-scale infrastructure development [11]. The results of this study also indicate the condition of women's vulnerability to individual factors. Women are vulnerable to their livelihoods because before the disaster they were generally not the main breadwinners. Access to housing is limited due to limited mobility. Women also need the availability of water and sanitation facilities that can provide privacy in their fulfilment. Various vulnerabilities faced by women can trigger mental conditions that require psychosocial assistance.

\subsection{Women's roles in disaster management}

In a vulnerable condition, women actually have more motivation than men in taking disaster management actions. Women not only care for the health of their family members but also pay more attention to the health of the wider community. The women helped clean up the trash carried by the floods in their neighbouring area. Disaster management work also includes women in seeking humanitarian assistance. This is different from the image presented by the media of women as cowardly victims and passive actors. In humanitarian work, women are actively involved in seeking humanitarian assistance as well as the distribution of goods and disaster response services. Although it must be admitted that the forms of women's participation and volunteerism become heavier when it comes to dealing with gender-based labour division norms [4].

In Bantul, Yogyakarta, when the earthquake occurred on 27 May 2006, women moved to build a soup kitchen. They split the task quickly to collect salvageable food in each house and then set it up as a food barn for a few days. The famine that followed the disaster was reduced because of the dexterity of women to act to protect the basic needs of their people. Entering the rehabilitation and reconstruction phase, a number of women's organizations practised another approach. Charitative assistance as part of philanthropy is very good for disaster response works. However, for long-term work, it does not educate the community, and it is feared that it will lead to community dependence on aid providers. Therefore, in the rehabilitation and reconstruction phase, charitable work sought to be integrated with the empowerment of the victim's community [12].

In Kinahrejo, Cangkringan, Sleman, Yogyakarta, the presence of women in the face of disasters had been seen since the evacuation period before the eruption of Mount Merapi. Social capital in the form of a sense of togetherness that characterizes agrarian societies was sufficient to assist victims in alleviating trauma. The method taken was through daily communication among 
survivors. The nangga or chatting culture in Javanese society contained the release of sadness, fear and boredom during the evacuation. The key to the successful resilience of women victims of the eruption in Kinahrejo was the characteristics of their community that uphold togetherness [10].

Women are known for their caring, protective, painstaking and diligent characters. The characters of women that are formed from the social construction in the family and community environment can help themselves and their families through the critical period after a disaster. Support from family is an important factor for positive changes in the mental health of disaster victims [13].

The characters of women also contribute to encouraging the transformation from being limited to only helping the family to help the community in general. This transformation can be seen from the activities in the soup kitchen in managing assistance for the common interest. Activities in the soup kitchen are scheduled. The kitchen, which is often identified with the domestic space of women, actually shows the existence and role of women who are actually part of public services. Management of a soup kitchen requires organizational competence so that it cannot be seen as a mere domestic activity. Soup kitchens are an arena for actualizing the existence and role of women during disasters. Women are also prominent in the distribution of basic food logistics at the evacuation posts. They spontaneously and from individual initiatives mobilized the distribution of logistics whose seeds were rooted in the general characteristics of Kinahrejo community [10].

In Meulaboh, West Aceh, there was a group of women who were steadfast in defending their village, which had been half lost to the sea. They fought for their rights right up to the DPRD (Regional House of Representatives). They insisted that the DPRD allow them to return to their village. Although there were suggestions not to live less than 300 meters from the shoreline, the ocean is also their home so there is nothing to worry about. They voiced their aspirations to the DPRD, while the men supported from behind. Their struggle was successful and attracted the attention of various international institutions [14].

In Pangandaran, there is the figure of $\mathrm{Bi} \mathrm{Ee}$, an elderly woman who continues to struggle to maintain her family life by opening a rujak shop. There is $\mathrm{Bu}$ Gendut, a middle-aged woman who lives alone and continued to sell in evacuation tents. There are also Teh Nur and Teh Dede, two young women who continued to activate Posyandu (Neighborhood Health Center) in the evacuation camps. They continued to struggle even with all their limitations. Teh Dede, although not a victim, also continued to accompany young mothers to activate Posyandu activities in evacuation camps [15].

Thus, the role of women in disaster risk management in Indonesia is quite significant. They act as initiators or mobilizers to take disaster risk reduction actions in their environment. However, they are also faced with various challenges, both internal and external. Internally, it is in the form of emotional control problems and dependence on others. Externally, it is in the form of lack of opportunities to improve competence in organizing disaster response and lack of safety guarantees [16].

During the hustle and bustle of disaster situations and women's struggles to maintain the survival of their families and communities, there are issues of women's rights that have been neglected, especially in disaster situations. The low involvement in public affairs and access to resources is a general description of the condition of women in Indonesia. The most dominant causative factor is a gender-biased life system. The rights of women cannot be guaranteed properly. This condition is even more difficult in a disaster situation. The feeling of security is further away and the opportunities for empowerment are getting smaller.

\subsection{Fulfilment of Women's Rights}

Women are more vulnerable to disasters because of their socially established roles. Genderbased social construction builds a social word in which natural occur [4]. The right of women in gender-based social construction will be carried over in disaster situations. women are faced with high vulnerability under abnormal conditions due to disasters.

The discourse on women's right is actually very classic. Its historical roots can be traced to the Greek's concept of state and citizen. At the time, in the polis (city-state), the interest of the state was above the interests of the individual. The polis made citizens equal. Every individual citizen could play a role in state affairs but with the exception of the minority from among immigrants, slaves, and women [17]. Women were not taken into account in every policy decision making. The task of women in state life was only related to reproductive function. It was men who played a role in the realm of state policy or public policy. According to Plato, in the city-state (polis), collectivity (togetherness) must be cultivated. Therefore, women and children belonged to the state. The state-regulated all aspects of community life so that the interests of the state do not mix with the interests of the family. Women were tasked with giving birth to a goodquality generation for the country [18]. Democracy 
in the Greek tradition above does not seem to involve women. The reason women are marginalized in state life is largely due to the fulltime role of women in the domestic sphere. This full responsibility in the domestic sphere makes it difficult for women to participate in the public sphere as citizens (Ackers, 1996).

Mary Astell, a feminist figure, stated in 1700 that political rights, especially the right to vote in general elections, were a difficult issue that was fought by women at that time. The right to nurture, access to education, the property right, the right to a living wage and the right to divorce were the focus of the struggles of early feminists in Western countries [19]. In subsequent developments, there have been many instruments, both national and international, which guarantee women's rights in various fields of life. The 1979 Convention on the Elimination of All Forms of Discrimination Against Women (CEDAW) guarantees equal rights between men and women in all aspects of life. Indonesia has ratified CEDAW through Law number 7/1984 dated 24 July 1984. CEDAW gave a mandate to countries that ratify it, among others, to amend or abolish laws, regulations, customs and practices that are discriminatory against women (Article 2).

In Indonesia, human rights (HAM) and the rights of citizens are guaranteed in the 1945 Constitution. These rights are recognized and guaranteed for both men and women regardless of ethnicity, religion and political choice. Everyone has the right to be free from discriminatory treatment on any basis and is entitled to protection from discriminatory treatment. Thus, if there are provisions or actions that discriminate against citizens, it means violating human rights and the 1945 Constitution. Every Indonesian woman citizen has the same constitutional rights as men [20].

Women are citizens who need special treatment related to their conditions. They will not get access to protection and fulfilment of rights without special treatment due to differences and differentiation by the structure of the patriarchal society. Protection and fulfilment of rights without special treatment will tend to maintain discrimination against women. Law Number 39/1999 on Human Rights affirms that everyone (men and women) has the right to protection of human rights and human freedoms without discrimination (Article 2). Law Number $12 / 2005$ concerning the Ratification of the International Covenant on Civil and Political Rights (Civil and Political Rights Law) affirms that women's civil and political rights are protected without discrimination (Articles 3 and 45).

Regarding women's rights in disaster situations, Law number 24/2007 concerning Disaster Management which came into effect on 26 April 2007 emphasizes that protection of vulnerable groups is carried out with priority on rescue, evacuation, security, health services and psychosocial services (Article 55 Paragraph 1). The vulnerable groups as referred to in paragraph (1) consist of: a) infants, toddlers and children; b) mothers who are pregnant or breastfeeding; c) people with disabilities; and d) elderly people (Article 55 Paragraph 2).

\subsection{Gender-based disaster response}

Women have a higher vulnerability during a disaster because of the social and cultural constructs that are imposed on them as women or often referred to as gender constructs. In a society with a strongly patriarchal culture, women's mobility is limited, because women are tied to the obligation to carry out reproductive functions and domestic work. This isolated condition often puts women in unsafe conditions. When a disaster occurs, women are in the house which is a greater condition threatening the safety of their lives, including the safety of their children. Meanwhile, men, who are constructed as breadwinners, are mostly in public spaces. Mobility also affects women's vulnerability. Men have wider access to disaster information and benefit more from their flexible mobility in public spaces. On the other hand, actually, men have a big responsibility to save their wives and children, not only to save themselves.

Inequality in power relations in a patriarchal society results in the subordination or marginalization of women. A society or community with a strongly patriarchal culture is a fundamental factor that continuously and constantly shapes women's vulnerability. In society, there is a tendency that since childhood women are not equipped with the ability to save themselves such as swimming, running fast, or climbing to higher places. In fact, these basic abilities will be very helpful, especially when living in a disaster-prone area.

In Indonesia, Murtakhamah identifies gender injustice that can occur in the middle of a disaster. The first is stereotypes or labelling. Women are labelled with a gentle character and men are labelled with a strong character. According to Yuliani, the characteristics of boys are aggressive, competitive, confident, want to appear and higher self-esteem than girls [21]. This condition can make women positioned in a weak condition. The map of women's participation in disaster management is limited and is often only positioned as the party caring for the injured, taking care of the household (soup kitchen) and food supplies. Meanwhile, men play a strategic role in gaining access to assistance and controlling the posts, as well as dealing with outsiders.

Second, subordination, namely the assumption that one sex is more important than the other sex. 
Women are viewed as inferior to men so that women are disadvantaged in disaster situations. Her needs as a woman in disaster situations are often neglected. The distribution of assistance to women, especially mothers, was usually in the form of cooking utensils. This seems to reinforce the view that the task of women is only related to kitchen affairs or cooking. Women's special needs such as sanitary napkins, underwear and other reproductive health devices are often not available.

The third, economic marginalization. Women during a disaster often cannot access assistance because they are considered not to be the head of the family or the main breadwinner. This condition is very detrimental to women, especially women who are left by their husbands, either before or after a disaster, and must become the head of the family. The lives of women are getting harder and harder. Access to assistance or other resources such as skills training or business capital credit.

Fourth, the double burden, that in disaster situations women often have to bear several workloads at once. Women have to take on household chores such as providing food, caring for children, caring for the sick and the elderly. On the other hand, women also bear the burden of livelihood because their husbands, who are victims of the disaster, leave them behind. Fifth, violence. In unstable disaster conditions with limited access to many things, overcrowded evacuation camps and high levels of stress, women can face various threats of violence such as sexual harassment or domestic violence [22].

Gender roles affect the condition of women during a disaster. The division of labour in the domestic sphere or inside the home and the public sphere or outside the home creates an effect on the differences in access to disaster information between men and women. Men who generally work outside the home will find it easier to get early warning information than women who mostly stay at home. Cultural factors affect the mobility of women and men. In some societies, the decision to leave the house is in the hands of the husband, so the wife tends to wait. The clothing factor worn by women in the form of long dress or skirt can also reduce the ability to run. The role of women as those in charge of caring for children and the elderly has caused many women to bring their children and elderly people along, thus slowing mobility during evacuation. In terms of survival, many women do not have the ability to swim and climb trees, making it difficult to save themselves. The expectation of women to be feminine results in things that are deemed appropriate and inappropriate for men and women to do [7].

Various legal instruments have guaranteed women's rights, including in disaster situations. However, unbalanced gender relations that have been deeply rooted in society still occur which have an impact on the daily living conditions of women and men, both in situations before a disaster, during a disaster, and after a disaster. The social construction that places the role of men in the public sphere allows them to have greater access to various resources. On the other hand, women who are placed in the domestic sphere due to the sociocultural construction of society make them have more limited opportunities and access to various resources as well as their individual mobility. In Pakistan, Pakistani society is all-gender bias it is not gendered friendly. Women's education especially in rural areas is not common because of norms and customs [23]. In Nigeria, gender distinction is only needed to allocate the work/task fairly as physically both have distinctive features [24]. In Turkey, research on gender found that women and men had different scores in certain respects [25]. In Sweden, women shall be involved in business to survive and to maintain their status and emancipation [26]. This condition can lead to gender injustice in disaster situations.

Women are less involved in designing programs or activities that are important to deal with disasters or reduce disaster risk, even though women are a vulnerable group. One of the causes is disaster management policies that do not pay attention to gender issues, which results in inequity towards women. Generally, disaster victims are seen as a homogeneous group by the makers and implementers of disaster management policies, even though the same disaster can have different impacts on men and women. Community perceptions of disasters are often not neutral, even though women are the most at risk.

In disaster-affected areas, the failure to recognize women as the head of the family makes many women end up not receiving assistance. To obtain assistance, they usually put the name of their dead husband. Woman refugees who live in people's houses often do not receive assistance because their basic needs are considered to have been fulfiled by their families. Gender relations have an impact on the condition of women during a disaster.

In the early 1970 s, the concept of ecofeminism developed. This concept tries to explain the relationship between feminism and ecology or the environment. The injustices that occur in the life of the human community are reflected in the destructive relationship between humanity and the natural world. This concept pays attention to environmental damage caused by contemporary socio-economic and military systems and analyzes the burdens, costs, responsibilities and roles that women must play due to environmental damage [27]. 
The environment cannot be separated from women's affairs. Women and nature have symbolic similarities because they are both controlled by a patriarchal culture. There are unfair power relations in practices related to the environment, the marginalization of women and environmental damage. Unequal power relations between women and men affect the type of assistance when a disaster occurs which results in the lack of attention to women's rights.

Disaster situations can be an opportunity to tackle gender inequality and advance women's rights. After the 2004 tsunami in Aceh and North Sumatra, the Aceh Women's Congress was held in June 2005. The congress was attended by more than 400 women from 21 civil society organizations. The meeting resulted in the Aceh Charter on Women's Rights, which contains personal rights, legal rights, political, social, economic and cultural rights in the Aceh context which are specifically related to Sharia law for women. The Aceh and Nias Reconstruction and Rehabilitation Agency (BRR) used gender equality as a basic principle in postdisaster recovery with support from various international organizations [4]. One of the women's rights is land ownership rights as one of the flagship programs. After the tsunami in Aceh, it is estimated that for $30 \%$ of the cases, women are registered as landowners [28]. The joint land ownership policy between husband and wife was adopted in September 2006.

Basic health service activities can be carried out by involving men and women so that there is awareness on both sides. Community health cadres can share tasks based on local consensus and customs. In the early stages, cadres of the Pos Pelayanan Terpadu or Posyandu (neighbourhood health center) are women with the main task of fulfiling nutrition, while for the Pos Obat Desa (Village Medicine Post), in which the health funds are managed, is handed over to men as decisionmakers.

Likewise in the daily life of group members. The role of health care and maintenance can be emphasized in the proportionate division of tasks and responsibilities between men and women. For example, controlling the quality of food is the duty and responsibility of women, while men are responsible for healing or bringing children/families for treatment.

In the condition when men cannot be directly involved in groups (such as groups of pregnant and lactating women), examination of pregnant women, child health and nutrition, it is necessary to involve men in order to have the awareness that to have healthy children and family, their role is required. The role of men is not only limited to as the breadwinner, but also the role of maintenance, adequate nutrition assurance and treatment. Such a method can strengthen the division of public and domestic spaces between men and women. However, the most important thing is the involvement of both parties according to their function. Gradually, it is necessary to initiate changes that provide equal opportunities for men and women in development programs in other fields after the disaster.

The problem of women's vulnerability during disaster-prone conditions in Indonesia can be anticipated with gender-based sustainable disaster response education that involve men and women with attention to women's rights in disaster through formal and non-formal education. Collaboration between the government and the community will increase community knowledge related to disaster reduction [29]. Disaster knowledge is very effective if it has been developed since elementary school [30].

Education is a very appropriate way to provide an understanding of the character of the awareness of the response to disaster and then foster a response attitude to disaster [31]. Disaster knowledge could be passed on to future generations, especially in disaster-prone areas [32]. According to Widodo and Hastuti, local wisdom education also is needed through formal and nonformal education. The government should look at local wisdom as a barrier to policy, but it can be a good collaboration in an effort to respond to the disaster. Local wisdom, generally not written and not massively taught by parents to children or youth, can cause the loss of the relay of perpetrators of local wisdom [33].

\section{CONCLUSION}

Women are among the vulnerable groups in disaster situations which result in a large percentage of the number of victims. In such conditions, women can actually act as mobilizers for families and communities in disaster risk management efforts. During disaster and women's struggles to maintain the survival of their families and communities, women's rights tend to be neglected. The most dominant causative factor is the sociocultural construction which is still gender-biased. The rights of women cannot be guaranteed properly. This condition is getting more difficult for women in disaster situations in fulfiling their rights. The problem of women's vulnerability during disaster-prone conditions can be anticipated with gender-based sustainable disaster responses education that involve men and women with attention to women's rights in disaster through formal and non-formal education. 


\section{REFERENCES}

[1] UNDP. Making Aceh Safer through Disaster Risk Reduction in Development. United Nations Development Programme and Government of Indonesia, 2012.

[2] Kemenkumham, Undang-undang Republik Indonesia Nomor 24 tahun 2007 Tentang Penanggulangan Bencana. Jakarta: Kemenhukham, 2007.

[3] Dharmodjo S. Proses Bermukim Masyarakat Marjinal Pasca Bencana Gempa Dan Tsunami Di Nanggroe Aceh Darussalam - Indonesia: Studi Kasus Masyarakat Marjinal di Sekitar Pelabuhan Malahayati, Aceh Besar. Seminar Internasional Institut Teknologi Sepuluh November, Surabaya, 17-18 Nopember 2005.

[4] Enarson E. Women Building their Future: Gender Breakthroughs in Post-Tsunami Aceh. UNIFEM, 2009.

[5] UNIFEM. Women's Voices in Aceh Reconstruction: The Second All-Acehnese Women's Congress. UNIFEM, 2006.

[6] Oxfam. The Tsunami's Impact on Women. Oxfam Briefing Note, March 2005.

[7] Oxfam. United Nations Office for Disaster Risk Reduction,2009.

[8] Huberman M.B., Miles A.M. Qualitative Data Analysis: A Sourcebook of New Method. Sage Publication, 2014.

[9] Haryono T.J.S., Koesbardiati T., Kinasih E. Model Strategi Mitigasi Berbasis Kepentingan Perempuan pada Komunitas Survivor di Wilayah Rawan Banjir. Departemen Antropologi, FISIP, Universitas Airlangga Surabaya, 2008.

[10] Waryono, Noorkamilah and Gazali H. Resilience Perempuan dalam Bencana Alam Merapi: Studi di Kinahrejo Umbulharjo Cangkringan Sleman Yogyakarta. Jurnal Ilmu Kesejahteraan Sossial, 1(1), 2012, http://digilib.uinsuka.ac.id/13929.

[11] Fordham M. The Place of Gender in Earthquake Vulnerability and Mitigation. Anglia Polytechnic University: Disaster Studies Project, 2000.

[12] Fatimah D., and Agustin R. Perempuan dan Kerelawanan dalam Bencana: Studi Kasus Penanganan Bencana di Kabupaten Bantul, DIY. Yogyakarta: Perhimpunan Aksara, 2007.

[13] Sukarni R., Krisnatuti D., and Herawati T. Dukungan Sosial dan Fungsi Keluarga Pascagempa di Wilayah Pegunungan dan Pesisir Kabupaten Lombok Timur. SOSIO KONSEPSIA, 8(03), 2019, pp. 303-320, https://doi.org/10.33007/ska.v8i3.1783.

[14] Hartono Y.. Laporan Akhir Respon Bencana Tsunami Bidang Community Organizer YEU Area Meulaboh Aceh Barat. Yogyakarta: Yakkum Emergency Unit, 2006.
[15] Hartono Y. Laporan Akhir Respon Bencana Tsunami Pangandaran Bidang Community Organizer. Yogyakarta: Yakkum Emergency Unit, 2008.

[16] Krisna A. Peranan relawan Perempuan sebagai Agen Perubahan Dalam Masyarakat Pada Upaya Pengurangan Resiko Bencana di Indonesia (Studi Kasus PerempuanPerempuan Relawan yang Bekerja Pada Organisasi Pengurangan Resiko Bencana. Laporan Hasil Penelitian: FPIPS UPI Bandung, 2008.

[17] Bertens K. Sejarah Filsafat Yunani. Yogyakarta: Kanisius, 1994.

[18] Noer D. Pemikiran Politik di Negeri Barat. Jakarta: Mizan, 1996.

[19] Humrn M. The Dictionary of Feminist Theory. England: Prentice-Hall, 1999.

[20] Asshiddiqie J. Hak konstitusional Perempuan dan Tantangan Penegakannya. Dialog Publik dan Konsultasi Nasional Komnas Perempuan, "Perempuan dan Konstitusi di Era Otonomi Daerah: Tantangan dan Penyikapan Bersama. Jakarta, 27 Nopember 2007..

[21] Yuliani S. Difference gender on mastery of language reviewed from psychology learning perspective. Pedagogia: Jurnal Ilmiah Ilmu Pendidik, 13(1), 2013, pp. 47-51.

[22] Murtakhamah T. Pengalaman Perempuan dan Inisiasi Pusat Krisis Berbasis Komunitas untuk Pengurangan Resiko Bencana. Konferensi Nasional Pengurangan Resiko Bencana Berbasis Komunitas VII, Yogyakarta tanggal 5-8 Desember 2011.

[23] S. Khatoon S, et.al. Blogging in ESL classgender-based attitude of the engineering students. International Journal of Evaluation and Research in Education, 9(4), 2020, pp. 1128-1137, 10.11591/ijere.v9i4.20673.

[24] Martin L.M. Boards of directors and gender diversity in UK companies. Gender in Management: An International Journal, 23(3), 2008, pp. 194-208, 10.1108/17542410810866944.

[25] Dirilen-gumus O., and Buyuksahin-sunal A. Gender differences in Turkish undergraduate students' values. Sex Roles, 67, 2021, pp. 559-570, 10.1007/s11199-012-0197-4.

[26] Ericsson T. Women, family, and small business in late nineteenth century Sweden. Histrory of Family, 6(2), 2001, pp. 225-239, 10.1016/S1081-602X(01)00068-9.

[27] Warren K.. Ecological Feminist Philosophies: An Overview of the Issues in Karen J. (Ed). Ecological Feminist Philosophies. Bloomington and Indianapolis: Indiana University Press, 1996. 
[28] Harper E. Guardianship, Inheritance and Land Law in Post-Tsunami Aceh. International Development Law Organization, 2007.

[29] Ikeda S., and Nagasaka T. An emergent framework of disaster risk governance towards innovating coping capability for reducing disaster risks in local communities. International Journal of Disaster Risk Science, 2(2), 2011, 10.1007/s13753-011-0006-7.

[30] Atmojo S.E., et.al., "The reconstruction of disaster knowledge through thematic learning of science, environment, technology, and society integrated with local wisdom. Jurnal Pendidikan IPA, 7(2), 2018, pp. 204-213, 10.15294/jpii.v7i2.14273.

[31] Darysyani D. Problem Posing Learning Model For Developing Students' Natural Disaster Responsiveness Characeters in Indonesia (A Case Study in State Senior High Schools in Kerinci). Sumatra Journal of Disaster, Geography and Geography Education, 1(2), 2017, pp. 307-314, https://doi.org/10.24036/sjdgge.v1i2.65.

[32] Syahputra H.. Indigenous knowledge representation in mitigation process: A study of communities' understandings of natural disasters in Aceh Province, Indonesia. Collection and Curation, 38(4), 2019, pp. 94102, 10.1108/CC-11-2017-0046.

[33] Widodo E., and Hastuti. Local Wisdom in Responding to Disaster of Merapi Eruption: Case Study of Wonolelo Village. GEOSFERA Indonesia, 4(3), 2019, pp. 264 279, 10.19184/geosi.v4i3.14066. 